\title{
Microwave Frequency
}

\section{Characterization of Barium Titanate}

\section{Films Obtained Via Sol-Gel}

José-Ignacio Marulanda-Bernal; Wilson-Henry Gallo-

Castrillón; Diana-Marybel Mosquera-Palacio

Citation: J.-I. Marulanda-Bernal, W.-H. Gallo-Castrillón, D.-M. Mosquera-Palacio, "Microwave Frequency Characterization of Barium Titanate Films Obtained Via Sol-Gel," Revista Facultad de Ingeniería, vol. 29 (54), e10416, 2020. https://doi.org/10.19053/01211129.v29.n54.2020.10416

Received: September 16, 2019; Accepted: December 02, 2019; Published: December 03, 2019

Copyright: This is an open access article distributed under the terms of the $\underline{\mathrm{CC} B Y}$

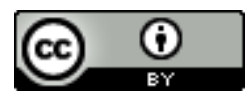

Competing interests: The authors have declared that no competing interests exist. 


\title{
Microwave Frequency
}

\section{Characterization of Barium Titanate Films Obtained Via Sol-Gel}

\author{
José-Ignacio Marulanda-Bernal ${ }^{1}$ \\ Wilson-Henry Gallo-Castrillón ${ }^{2}$ \\ Diana-Marybel Mosquera-Palacio ${ }^{3}$
}

\begin{abstract}
The present work focuses on the structural, morphological and dielectric characterization of barium titanate films (BTO or BaTiO3 due to its chemical formula) deposited by spin coating on crystalline silicon (Si) substrates and CPW resonators using the Sol-Gel technique with a $\mathrm{Ba} / \mathrm{Ti}$ molar ratio of $0.5 / 0.5$. The coplanar waveguides were manufactured on alumina substrates $\left(\mathrm{Al}_{2} \mathrm{O}_{3}\right)$ with $3 \mu \mathrm{m}$ of gold ( $\mathrm{Au}$ ) metallization using the laser ablation technique. The scanning electron microscopy (SEM) with X-ray energy dispersion spectrometry (EDS) showed the existence of a BTO film with an elementary composition of $14.62 \%$ barium and $5.65 \%$ titanium, with a thickness of $0.77 \mu \mathrm{m}$ measured using the profilometric mode of the atomic force microscopy (AFM). Dielectric characterization was carried out by comparing the frequency response (parameter $\mathrm{S}_{21}$ ) of a CPW resonator with deposited BTO film and another reference resonator (without film) using a network vector analyzer (VNA). These measurements are compared in turn with computational simulations to obtain the dielectric properties. For the BTO film a relative dielectric constant $\left(\varepsilon_{r}\right)$ of 160 was determined with a loss tangent $(\operatorname{Tan} \delta)$ of 0.012 for a frequency of 3.60 $\mathrm{GHz}$. The dielectric constant and the ferroelectric property of the material produced
\end{abstract}

\footnotetext{
${ }^{1}$ Ph. D. Universidad EAFIT (Medellín-Antioquia, Colombia). jmarulan@eafit.edu.co. ORCID: 0000-0001-62333407.

${ }^{2}$ M. Sc. Universidad EAFIT (Medellín-Antioquia, Colombia).whgalloc@eafit.edu.co. ORCID: 0000-0001-91967644 .

3 Universidad EAFIT (Medellín-Antioquia, Colombia). dmmosquerp@eafit.edu.co. ORCID: 0000-0003-0401$\underline{3557 .}$.
} 
are quite promising for applications in microwave circuits, such as miniaturization and tuning.

Keywords: dielectric constant; ferroelectrics; microwave materials; loss tangent; Sol-Gel; thin films.

\section{Caracterización en frecuencia de microondas de películas de titanato de bario obtenidas vía Sol-Gel}

\section{Resumen}

El presente trabajo se centra en la caracterización estructural, morfológica y dieléctrica de películas de titanato de bario ( $\mathrm{BTO}$ o $\mathrm{BaTiO}_{3}$ por su fórmula química) depositadas mediante la técnica que proporciona recubrimiento por medio de un sistema de rotación (spin coating) sobre substratos de silicio cristalino (Si) y resonadores CPW a través del método Sol-Gel, utilizando una relación molar Ba/Ti de $0.5 / 0.5$. Las guías de ondas se fabricaron sobre substratos de alúmina $\left(\mathrm{Al}_{2} \mathrm{O}_{3}\right)$ con $3 \mu \mathrm{m}$ de metalización en oro (Au) empleando la técnica de ablación láser. La microscopia electrónica de barrido (SEM) con espectrometría de dispersión de energía de rayos $X$ (EDS) permitió evidenciar la existencia de una película de BTO con una composición elemental de $14.62 \%$ de bario y $5.65 \%$ de titanio, además de un espesor de $0.77 \mu \mathrm{m}$ medido utilizando la modalidad perfilométrica de la microscopia de fuerza atómica (AFM). La caracterización dieléctrica se llevó a cabo mediante la comparación de la respuesta en frecuencia (parámetro $S_{21}$ ) de un resonador CPW con película de BTO depositada y otro resonador de referencia (sin película) usando un analizador vectorial de red (VNA). Estas medidas se comparan a su vez con simulaciones computacionales para obtener las propiedades dieléctricas. Para la película de BTO se determinó una constante dieléctrica relativa $(\varepsilon r)$ de 160 con tangente de pérdida $(\operatorname{Tan} \delta)$ de 0.012 para una frecuencia de 3.60 $\mathrm{GHz}$. La constante dieléctrica y la propiedad ferroeléctrica del material elaborado son características bastante promisorias para aplicaciones en circuitos de microondas, tales como miniaturización y sintonizabilidad.

Palabras clave: constante dieléctrica; ferroeléctricos; materiales en microondas; películas delgadas; Sol-Gel; tangente de pérdida. 


\section{Caracterização e Frequência de Micro-ondas de Películas de Titanato de Bário Obtidas Via Sol-Gel}

\section{Resumo}

O presente trabalho centra-se na caracterização estrutural, morfológica e dielétrica de películas de titanato de bário (BTO ou $\mathrm{BaTiO}_{3}$ por sua fórmula química) depositados mediante a técnica que proporciona recobrimento por meio de um sistema de rotação (spin coating) sobre substratos de silício cristalino (Si) e ressonadores CPW mediante a técnica Sol-Gel, utilizando uma relação molar $\mathrm{Ba} / \mathrm{Ti}$ de $0.5 / 0.5$. As guias de ondas fabricaram-se sobre substratos de alumina $\left(\mathrm{Al}_{2} \mathrm{O}_{3}\right)$ com $3 \mu \mathrm{m}$ de metalização em ouro ( $\mathrm{Au}$ ) empregando a técnica de ablação laser. $\mathrm{A}$ microscopia eletrônica de varredura (SEM) com espectrometria de dispersão de energia de raios $X$ (EDS) permitiu evidenciar a existência de uma película de BTO com uma composição elementar de $14.62 \%$ de bário e $5.65 \%$ de titânio, ademais de uma espessura de $0.77 \mu \mathrm{m}$ medido utilizando a modalidade perfilométrica da microscopia de força atômica (AFM). A caracterização dielétrica levou-se a cabo mediante a comparação da resposta em frequência (parâmetro $S_{21}$ ) de um ressonador CPW com película de BTO depositada e outro ressonador de referência (sem película) usando um analisador vectorial de rede (VNA). Estas medidas comparam-se a sua vez com simulações computacionais para obter as propriedades dielétricas. Para a película de BTO determinou-se uma constante dielétrica relativa $\left(\varepsilon_{r}\right)$ de $160 \mathrm{com}$ tangente de perda (Tan $\left.\delta\right)$ de 0.012 para uma frequência de $3.60 \mathrm{GHz}$. A constante dielétrica e a propriedade ferroelétrica do material elaborado são características bastante promissoras para aplicações em circuitos de micro-ondas, tais como miniaturização e sintonizabilidade.

Palavras chave: constante dielétrica; ferroelétricos; materiais em micro-ondas; películas finas; Sol-Gel; tangente de perda. 


\section{INTRODUCTION}

Ferroelectric materials are characterized for presenting a spontaneous polarization in absence of an electric field [1]. This particularity has brought electronic industries to use these materials in the $\mathrm{GHz}$ region for the optimization and miniaturization of measurement devices, frequency and telephony analyzers [2]. One of the most common ferroelectric materials applied in microwave frequency tuning is the barium titanate (BTO or $\mathrm{BaTiO}_{3}$ for its chemical formula) [3-7]. Said process can be made by depositing films of the material through Sol-Gel synthesis on resonators elaborated in Coplanar Waveguides (CPW) [8-9].

The So-Gel process consists in the preparation of a colloid stable solution ("Sol") from de precursors that produce a network of macromolecular oxide, that gels into a film when it dries [10-11]. Authors such as O. Harizanov et al, S. Sharma et al, y D. Tripkovic et al, used the Sol-Gel synthesis to obtain slim BTO films through deposition techniques such as dip coating, spin coating and Inkjet, respectively [10, 12-13]. In this paper the dielectric characterization of BTO is presented, so that it is possible to ensure a high $\varepsilon$ r under acceptable structural and morphological conditions.

\section{MetHOdS}

\section{A. Preparation of the BTO via Sol-Gel}

The procedure was adapted in a humid way and at room temperature $\left(22^{\circ} \mathrm{C}\right)$ for the Sol-Gel method reported by Balachandran et al [14], using as precursor the titanium isopropoxide (IV) or TTIP (Alfa A13703) and the barium acetate (Merck). In this sense, $0.387 \mathrm{~g}$ of barium acetate were mixed with $3.0 \mathrm{ml}$ of deionized water with constant agitation of $320 \mathrm{rpm}$, until the barium acetate was completely dissolved (solution 1). Then, $3.0 \mathrm{ml}$ of acetic acid were added to $0.468 \mathrm{ml}$ of TTIP until a homogenous mix was obtained (solution 2). Later, both solutions were mixed with a molar proportion $\mathrm{Ba} / \mathrm{Ti}$ of $0.5 / 0.5$. Then, ethylene glycol was added in a 1.1 relation to acetic acid. 
The BTO deposition was made at room temperature $\left(22^{\circ} \mathrm{C}\right)$ over crystalline silicon and CPW resonators, using a spin coater at $2000 \mathrm{rpm}$ during five seconds. The recovered substrates dried at room temperature and were submitted to a thermic treatment with rising temperature of $400{ }^{\circ} \mathrm{C}\left(1^{\circ} \mathrm{C} / \mathrm{min}\right)$, maintained at $900^{\circ} \mathrm{C}(5$ ${ }^{\circ} \mathrm{C} / \mathrm{min}$ ) during an hour, then cooled down by natural convection during 12 hours until they reached room temperature.

\section{B. Characterization of BTO films}

1) Atomic force microscopy. The measurement of the width for the crystalline silicon substrates and CPW resonators with BTO film was made using the intermittent contact mode without previous preparation of the sample. In order to do that, a Nanosurf $\AA$ microscope model Easyscan2 AFM was used, occupying a CT170R-25 probe with a conic form $15 \mu \mathrm{m}$ high, curvature ratio of $8 \mathrm{~nm}$ and resonance frequency of $170 \mathrm{kHz}$.

2) Sweep electronic microscopy. The analysis of sweep electronic microscopy (SEM) allowed us to determine the morphology of the BTO without a special preparation of the sample. A Phenom G2 pro® microscope was used with a $7 \mathrm{kV}$ voltage.

3) X-ray energy dispersion spectroscopy. The EDS analysis gave information about the elemental composition of the evaluated material, through the use of a thermionic JEOL-JSM 6490LV® microscope with a $16 \mathrm{kV}$ voltage. Before making the analysis, the samples were covered with gold through sputtering process.

4) Dielectric characterization. To perform the dielectric characterization CPW resonators as described by Marulanda et al [15] were elaborated. The Figure 1a shows the structural dimensions of the CPW that consist of a central conducting line $(s)$, two ground planes $(g)$, gap $(w)$, a gold metallization thickness $(f)$, an alumina polished substrate that covers all of the height $h$ and with relative permittivity $(\varepsilon r=$ 9.8). Additionally, the parameters $a, b$ and $c$ are shown, which make reference to the geometric parameters of the CPW. With the previous parameters, the design was defined (Figure 1b), to later elaborate the configuration model in CAD and use a LPKF ProtoMats ${ }^{\circledR}$ plotter to fabricate the CPW resonators (Figure 2). 


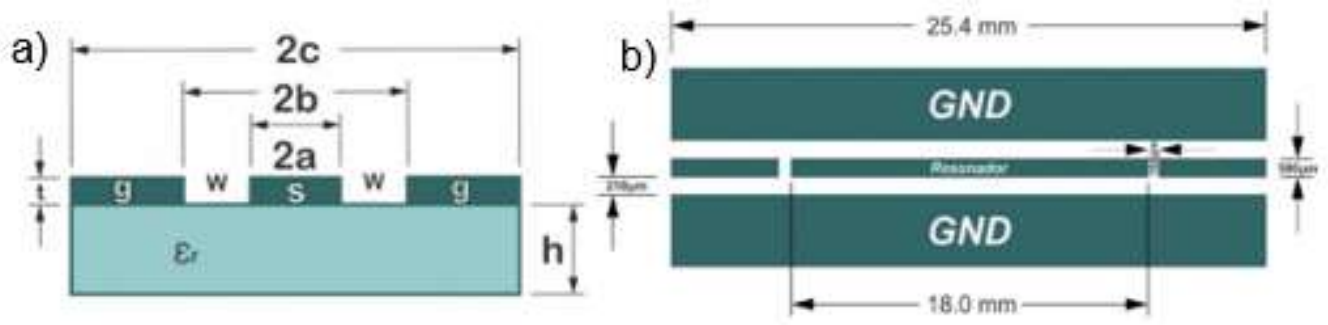

Fig. 1 CPW Transmission line a) Transversal section, b) Experimental design.

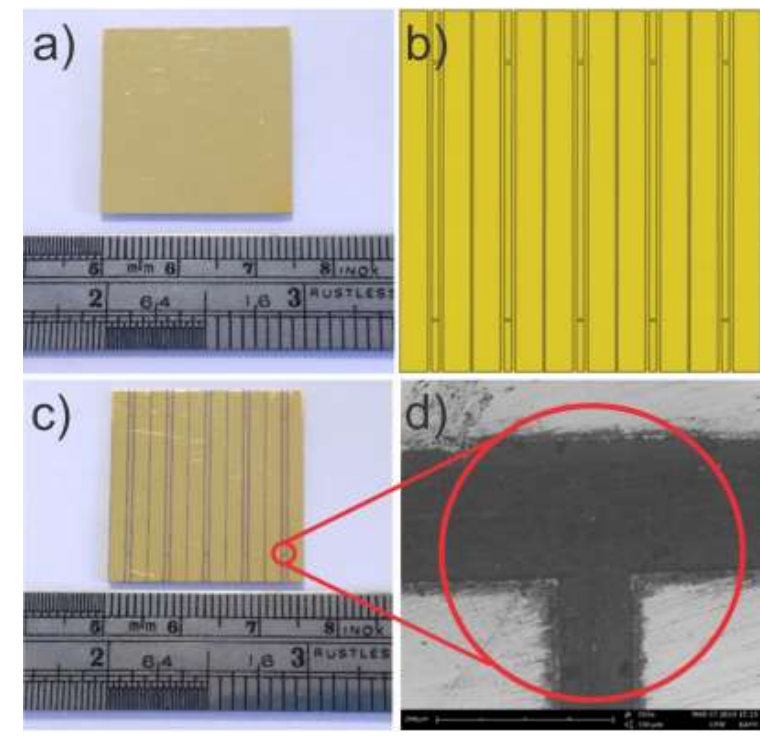

Fig. 2 Elaboration of CPW resonators. A) Superficial view of the dielectric substrate, b) CAD design of the CPW transmission line, c) Plot over the dielectric substrate, d) SEM image of the plot.

$1.00 \mathrm{~mm}$ of each border of the CPW circuit was isolated with vacuum and high temperature tape (Figure 3), to measure the thickness and correctly make the connections to the vector network analyzer. 


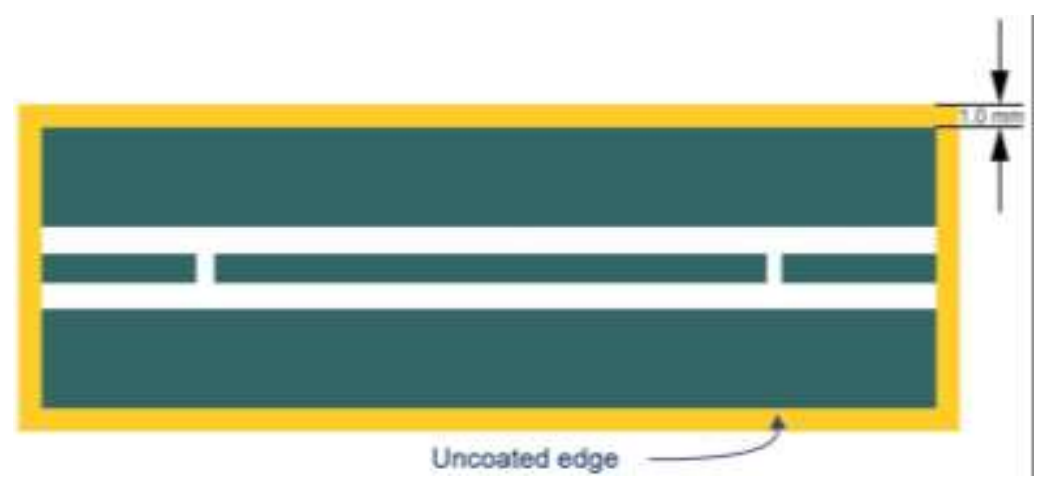

Fig. 3 Isolated borders of the CPW resonator.

5) Frequency Response of the resonator circuits. An Agilent $E 5063 A \circledast$ VNA of two ports was used with a measuring range between 0.1 and $8.5 \mathrm{GHz}$, and without previous preparation of the circuits that were joined to a RP SNA type coaxial ensemble (Figure 4). The measuring of the frequency response of the CPW+DUT was made for resonators with and without the BTO film, to avoid the displacement in the measures of the $S$ parameters.
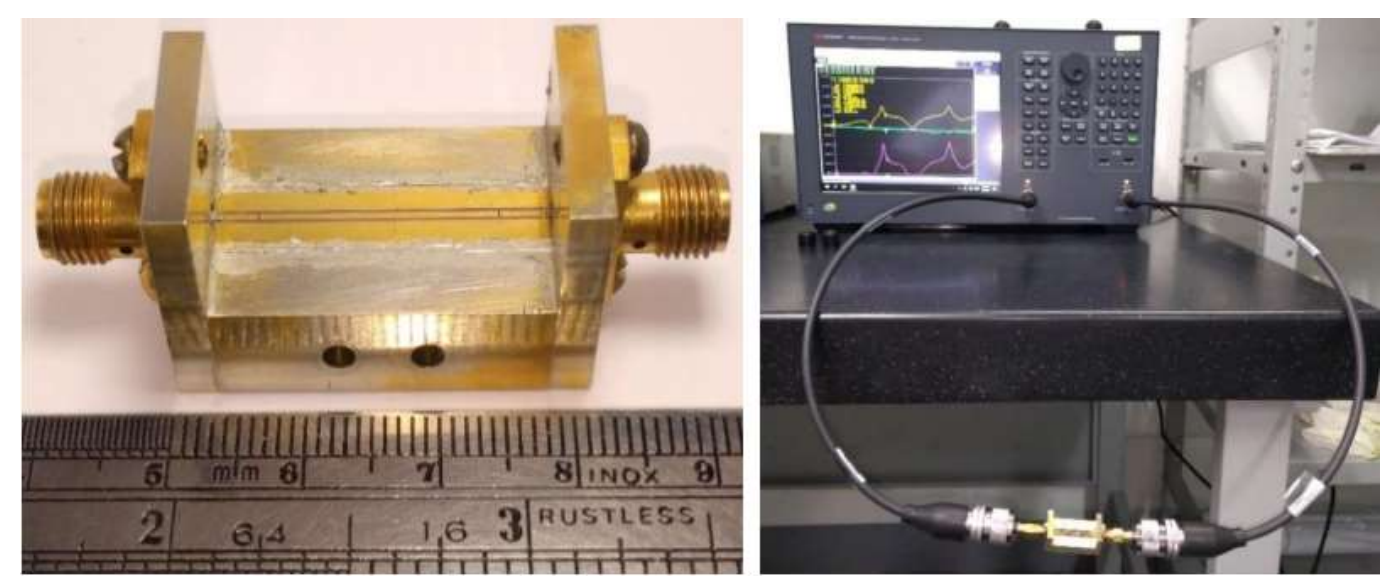

Fig. 4 Dielectric Characterization. a) CPW resonator located in a RP SMA type coaxial ensemble,

b) Vector network analyzer.

\section{RESULTS}

\section{A. Structural and Morphological Characterization}

In Figure $5 \mathrm{a}$ it is shown by the difference in the tonality the presence of the $\mathrm{BaTiO}_{3}$ film with a thickness of $0.77 \mu \mathrm{m}(770 \mathrm{~nm})$; superficial defects or scratches can be 
seen, generated by the action of the laser during the CPW circuit impression process (Figure $3 \mathrm{~d}$ ). Figure $5 \mathrm{~b}$ depicts the $\mathrm{BaTiO}_{3}$ film with the presence of separated nanoparticles with spherical shapes and average size of $4.10 \pm 0.46 \mu \mathrm{m}(4100 \pm 460$ $\mathrm{nm})$.

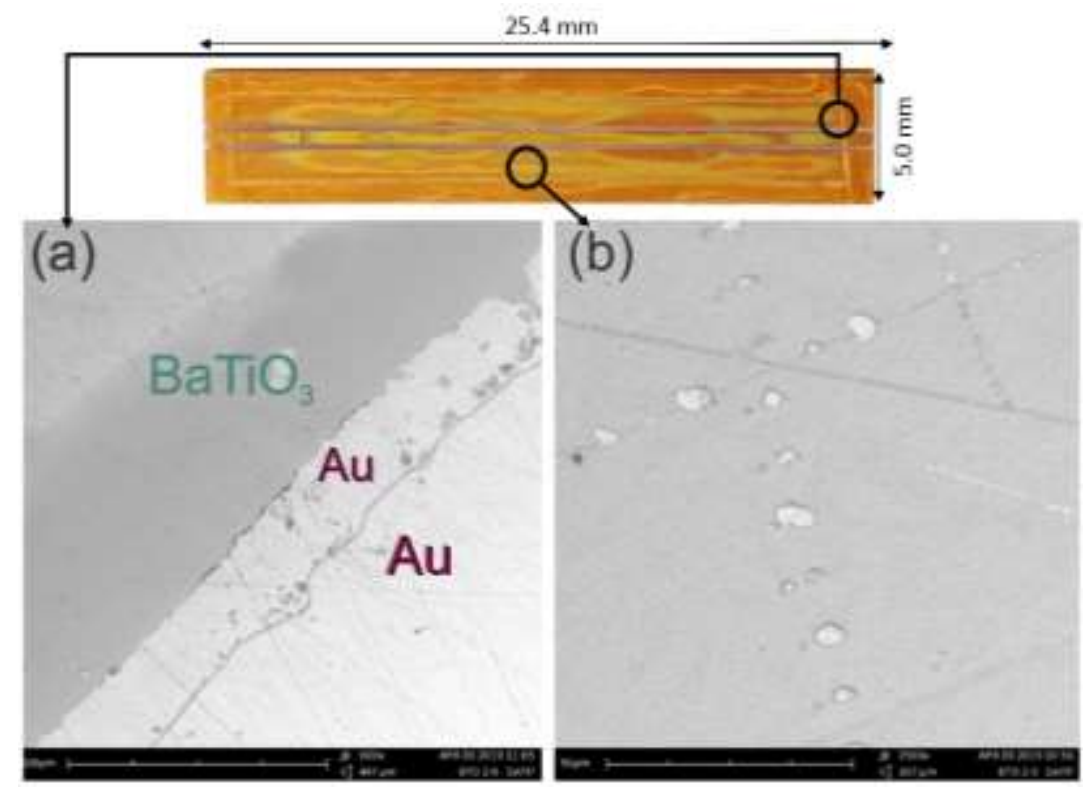

Fig. 5. $\mathrm{BaTiO}_{3}$ film morphology. a) Interface between the gold metallization (right) of the $\mathrm{CPW}$ resonator and the $\mathrm{BaTiO}_{3}$ film (left), b) $\mathrm{BaTiO}_{3}$ film deposited on the CPW resonator.

The EDS analysis was made for BTO layers deposited on a crystalline silicon substrate, these layers added a net thickness of $0.55 \mu \mathrm{m}(550 \mathrm{~nm})$. In Figure 6 it can be seen for the BTO layers deposited on a superficial morphology which is granular and composed of individual particles with homogeneous sizes of approximately 0.71 $\pm 0.37 \mu \mathrm{m}(710 \pm 370 \mathrm{~nm})$, which is attributed to the liquid phase synthesis process [7]. The elemental EDS analysis shows an elemental composition in atomic percentage of $14.62 \% \mathrm{Ba}(\mathrm{L}), 79.73 \% \mathrm{O}(\mathrm{K})$ y $5.65 \% \mathrm{Ti}(\mathrm{K})$. 


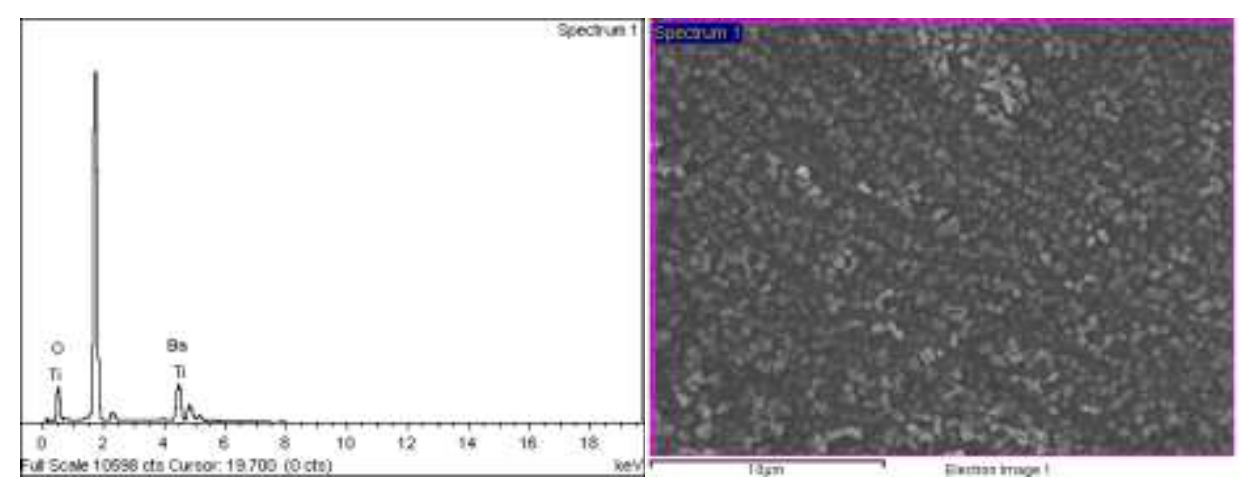

Fig. 6 EDS analysis for BTO films deposited on crystalline silicon substrate.

\section{B. Dielectric Characterization}

Figure 7 depicts the peaks of resonance obtained through the comparison of the $\mathrm{S}_{21}$ parameter measurements done with the VNA analyzed for the CPW with and without BTO film. By making a close up to the first peak with resonance frequency of 3.60 $\mathrm{GHz}$, a light displacement to a lower frequency of the CPW resonator with BTO film can be seen. Through simulations made with CST Microwave Studio Suite ${ }^{\circledR}$, a dielectric relative constant $\left(\varepsilon_{r}\right)$ of 160 was determined for the covering material (BTO) and a Tan $\delta$ of 0.012 . These results have similarities with those reported by [16], who obtained a dielectric constant of 120 to $10 \mathrm{kHz}$ for thin BTO films deposited by RF magnetron sputtering. Here it can be highlighted that the process of obtaining the particles defines the final dielectric characteristics of the material.

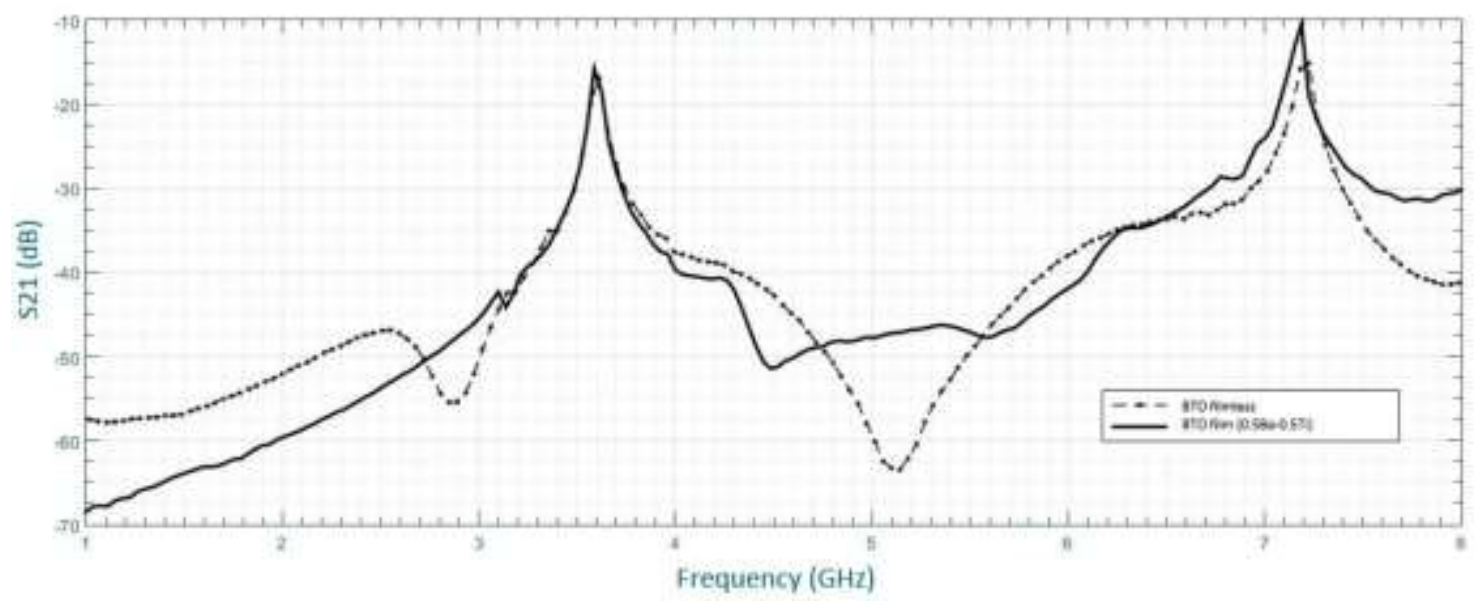

Fig. 7. Fundamental resonance peaks measured on CPW resonators with and without BTO content. 


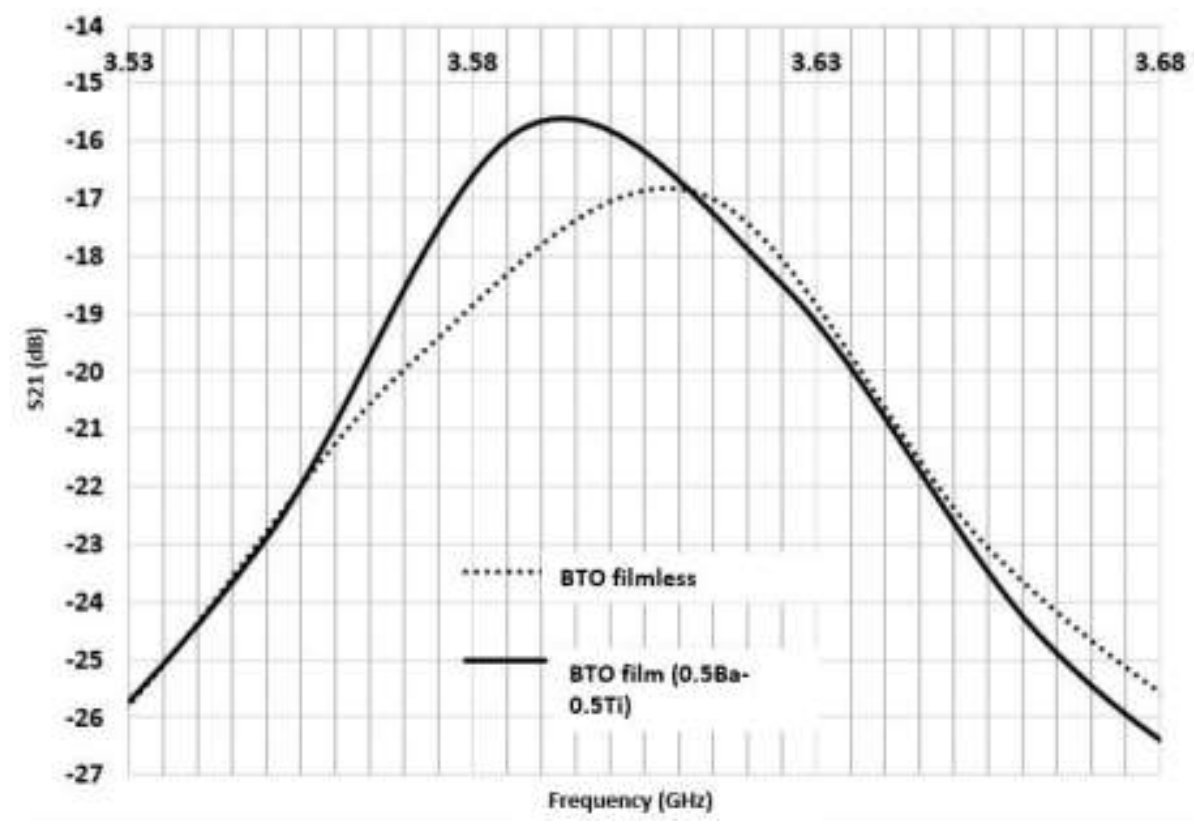

Fig. 8 Close up to the first peak of fundamental resonance of the CPW resonator with and without BTO content.

\section{Discussion AND Conclusions}

In the present paper, structural, morphological and dielectric characteristics of BTO films deposited on CPW resonators through the Sol-Gel technique are reported. Thicknesses of BTO film deposited on crystalline silicon substrates and CPW resonators of $0.55 \mu \mathrm{m}(550 \mathrm{~nm})$ an $0.77 \mu \mathrm{m}(770 \mathrm{~nm})$ respectively were obtained. Additionally, a dielectric relative constant $\left(\varepsilon_{r}\right)$ of 160 was determined for the BTO film, as well as a loss tangent (Tan $\delta$ ) of 0.012 for a resonance frequency of $3.60 \mathrm{GHz}$, dielectric characteristics that are of particular interest for microwave applications.

\section{AUTHOR'S CONTRIBUTION}

Marulanda-Bernal was the generator of the central idea of the investigation and the supervisor of the experimental processes performed and the results obtained; GalloCastrillón executed the experiments related with the fabrication of the CPW circuit and the preparation of the BTO films; and Mosquera-Palacio collaborated in the performances of the experimental Sol-Gel process to obtain the BTO films. 


\section{FUNDING}

The authors express their acknowledgment to the Universidad EAFIT for the founding of the internal project code 828-000031 "Materiales de Microondas", from which the results for this article were obtained.

\section{REFERENCES}

[1] M. E. Lines, and A. M. Glass, Principles and Applications of Ferroelectrics and Related Materials. Oxford, England: Oxford University Press, 2001.

[2] G. Alvarez, R. Zamorano, R. Font, J. Portelles, C. Román, M. Castellanos, and J. Heiras, "Mediciones del perfil de absorción de potencia a microondas en materiales ferroeléctricos y magnetoferroeléctricos," Superficies y Vacío, vol. 18 (1), pp. 11-15, Mar. 2005.

[3] S. H. Baek, J. Park, D. M. Kim, V. A. Aksyuk, R. R. Das, S. D. Bu, D. A. Felker, J. Lettieri, V. Vaithyanathan, S. S. N. Bharadwaja, N. Bassiri-Gharb, Y. B. Chen, H. P. Sun, C. M. Folkman, H. W. Jang, D. J. Kreft, S. K. Streiffer, R. Ramesh, X. Q. Pan, S. Trolier-McKinstry, D. G. Schlom, M. S. Rzchowski, R. H. Blick, C. B. Eom, "Giant Piezoelectricity on Si for Hyperactive MEMS," Science Journals, vol. 334 (6058), pp. 958-961, Nov. 2011. https://doi.org/10.1126/science.1207186

[4] A. Feteira, D. C. Sinclair, I. M. Reaney, Y. Somiya, and M. T. Lanagan, "BaTiO3-Based Ceramics for Tunable Microwave Applications," Journal of the American Ceramic Society, vol. 87 (6), pp. 1082-1087, Jul. 2004. https://doi.org/10.1111//.1551-2916.2004.01082.x

[5] R. Schafranek, A. Giere, A. G. Balogh, T. Enz, Y. Zheng, P. Scheele, R. Jakoby, and A. Klein, "Influence of Sputter Deposition Parameters on the Properties of Tunable Barium Strontium Titanate Thin Films for Microwave Applications," Journal of the European Ceramic Society, vol. 29(8), pp. 1433-1442, May. 2009. https://doi.org/10.1016/j.jeurceramsoc.2008.08.034

[6] P. W. M. Jacobs, E. A. Kotomin, A. Stashans, and I. Tale, "Theoretical Simulations of Hole Centres in Corundum Crystals," Modelling and Simulation in Materials Science and Engineering, vol. 2(1), pp. 109117, Jan. 1994. https://doi.org/10.1088/0965-0393/2/1/008

[7] H. Jiang, J. Zhai, and X. Yao, "Microwave Dielectric Properties of BaTiO3-SrZnP2O7 Composite Ceramics for Tunable Microwave Applications," Journal of Physics D: Applied Physics, vol. 42(22), pp.225-404, 2009. https://doi.org/10.1088/0022-3727/42/22/225404

[8] H. M. Wong, B. Luo, L. C. Ong, K. Yao, and Y. X. Guo, "Characterization of Dielectric Properties for PZNPMNPT Ferroelectric Thin Films at Microwave Frequencies," in Asia-Pacific Microwave Conference, Japan, 2006, pp. 579-582. https://doi.org/10.1109/APMC.2006.4429492

[9] L. F. Chen, C. K. Ong, C. P. Neo, V. V. Varadan, and V. K. Varadan, Microwave Electronics: Measurement and Materials Characterization, West Sussex, England: John Wiley \& Sons, 2004. https://doi.org/10.1002/0470020466

[10] O. Harizanov, A. Harizanova, and T. Ivanova, "Formation and Characterization of Sol-Gel Barium Titanate," Materials Science and Engineering: B, vol. $106 \quad$ (2), pp. 191-195, Jan. 2004. https://doi.org/10.1016/..mseb.2003.09.014 
[11] C. J. Brinker, and G. W. Scherer, Sol-Gel Science: The Physics and Chemistry of Sol-Gel Processing. San Diego, California: Academic press, 2013.

[12] S. Sharma, M. Tomar, N. K. Puri, and V. Gupta, "Ultraviolet Radiation Detection by Barium Titanate Thin Films Grown by Sol-Gel Hydrothermal Method," Sensors and Actuators A: Physical, vol. 230, pp. 175-181, Jul. 2015. https://doi.org/10.1016/i.sna.2015.04.019

[13] D. Tripkovic J. Vukmirovic, B. Bajac, N. Samardzic, E. Djurdjic, G. Stojanovic, and V. V. Srdic, "Inkjet Patterning of in Situ Sol-Gel Derived Barium Titanate Thin Films," Ceramics International, vol. 42 (1), pp. 1840-1846, Jan. 2016. https://doi.org/10.1016/j.ceramint.2015.09.148

[14] R. Balachandran, H. K. Yow, M. Jayachandran, W. Y. W. Yusof, and V. Saaminathan, "Particle Size Analysis of Barium Titanate Powder by Slow-Rate Sol-Gel Process Route," in IEEE International Conference on Semiconductor Electronics, Kuala Lumpur, Malaysia, 2006, pp. 406-409. https://doi.org/10.1109/SMELEC.2006.381091

[15] J. I. Marulanda, M. Cremona, R. Santos, M. C. R. Carvalho, and L. S. Demenicis, "Characterization of $\mathrm{SrTiO}_{3}$ Thin Films at Microwave Frequencies Using Coplanar Waveguide Linear Resonator Method," Microwave and Optical Technology Letters, vol. 53 (10), pp. 2418-2422, Jul. 2011. https://doi.org/10.1002/mop.26233

[16] J. Y. Hsu, J. Y. M. Lee, J. J. Wang, L. Y. Yeh, J. T. Lai, and J. Gong, "Electrical Properties of Barium Titanate Ferroelectric Thin Films Fabricated by RF Magnetron Sputtering for Memory Devices Application," in International Electron Devices and Materials Symposium, Hsinchu, Taiwan, 1994, pp. 11. https://doi.org/10.1109/EDMS.1994.863878

Revista Facultad de Ingeniería (Rev. Fac. Ing.) Vol. 29 (54), e10416. 2020. Tunja-Boyacá, Colombia. L-ISSN: 0121-1129, e-ISSN: 2357-5328, DOI: https://doi.org/10.19053/01211129.v29.n54.2020.10416 